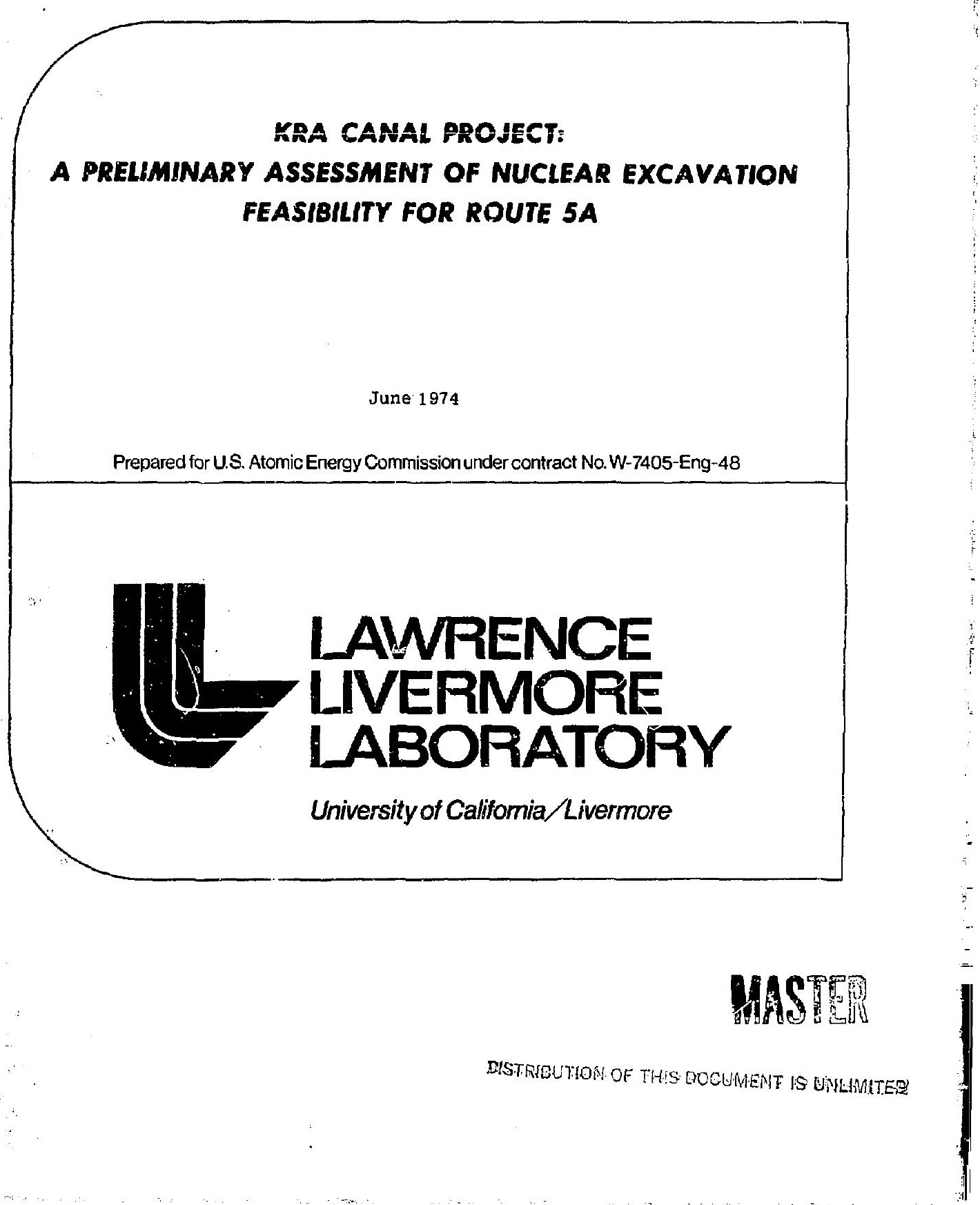



"This report was prepared as an account of wark sponsored by
the United States Government. Neither the United States nor the United States Government. Neither the United States nor the United States Aromic Energy Commission, nor any of ticir cmployess, mikies any warranty, express or implicd, or assun,cs any legal liabifity or responsibility for the aceuricy, completeness or userulness of any information, apparatus, product or process disclosed, or represents that jis use would not infringe privatelyowned tights."

Printed in the United States of America

$$
\text { Available from }
$$

National Technical Information Service

U.S. Department of Cnminerce 5285 Port Royal Road

Springfield, Virginia 22151

Price: Prinied Copy $\$$ _; Microfiche $\$ 0.95$

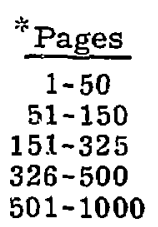

NTIS

Selling Price

$\$ 4.00$

$\$ 5.45$

$\$ 7.60$

$\$ 10.60$

$501-1000$

$\$ 13.60$ 
TID-4500, UC-35

Peaceful Applications

of Explosions

\section{迎 \\ LAWRENCE ISVERMORE LABORATORY \\ Univorsity or Cavitomia L hermora, Catromia 94550}

\section{UCRL - 51418 \\ KRA CANAL PROJECT: \\ A PRELIMINARY ASSESSMENT OF NUCIEAR EXCAVATION FEASIBILITY FOR ROUTE 5A}

John Toman, Howard Tewes, Keridall Peterson, Donald Emerson, Donald Monten, Thomat Gibson, Wayne Woodrufi, John Button,

William Robison, Yook Ng, Milo Nordyke, and Fred Holzer

MS. date: June 1974

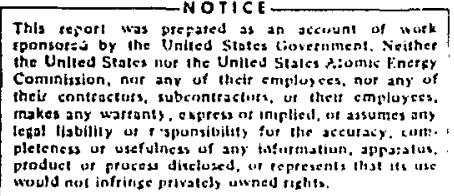




\section{Preface}

This document is the final version of a draft issued on 1 September 1973 as Appendix D of a report by TANIS and RRNA." The only noteworthy revisions of the draft report are in the section "Predicted Effects of the Nuclear Detonations: BioEnvironmental Considerations" and in Table 4. These changes reflect a recalculation of the amount of radioactivity deposited on the Nicobar Islands and Sumatra, as well as a revision of some of the deposition/dose conversion factors. As a result of these changes, the pasture-meat food pathway has been eliminated as a major contributor to population dose in Sumatra. Estimated radiation doses to the populations of both Nicobar and Sumatra are significantly lower than had previously been indicated.

\footnotetext{
TAMS: Tippetts-4bbett-McCarthy-Stratton, Consulting Engineers, New York, NY.

RRNA: Robert R. Nathan Associates, lnc., Consulting Economists, Washington, D. C. 


\section{Contents}

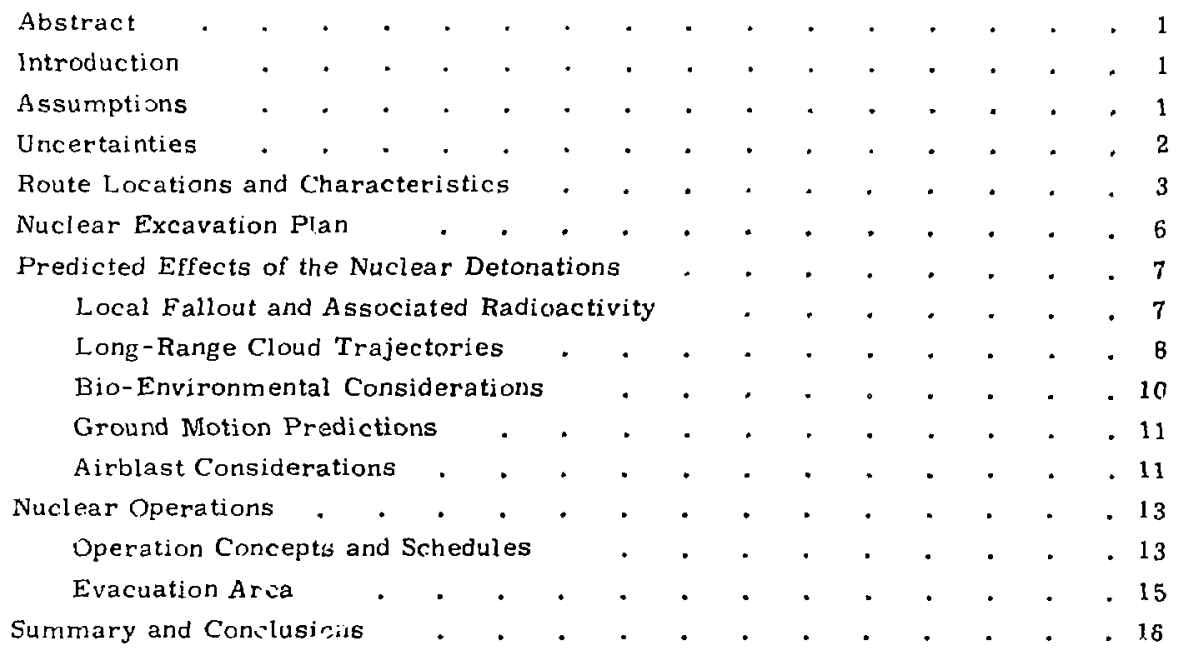




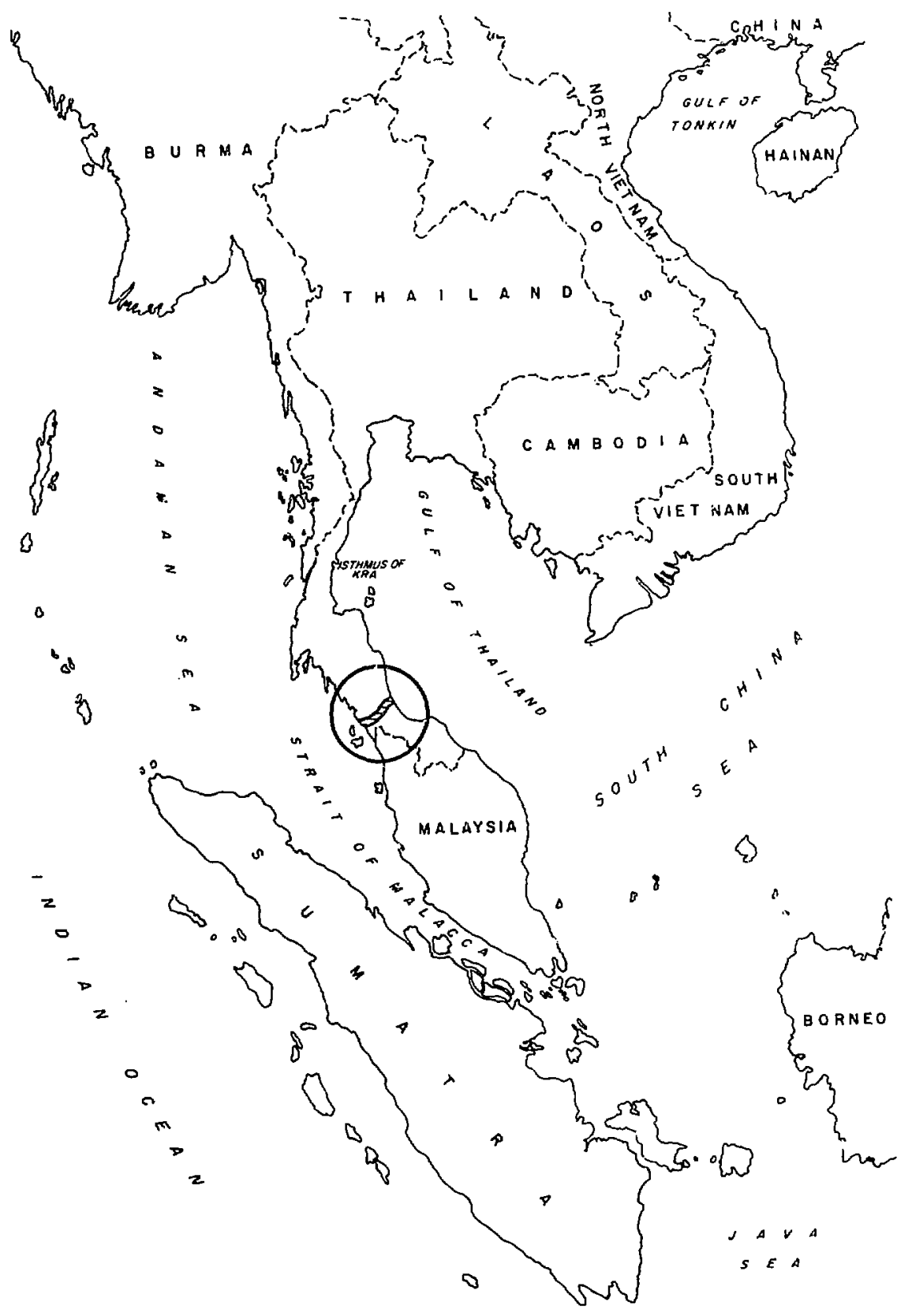

Frontispiece 


\title{
KRA CANAL PROJECT: \\ A PRELIMINARY ASSESSMENT OF NUCLEAR EXCAVATION FEASIBILITY FOR ROUTE 5A
}

\begin{abstract}
A preliminary survey of the possibility of excavating a portion of a canal across the Isthrinus of Kra with nuclear explosives has been completed. For the propesed route (designated $5 \mathrm{~A}$ ), a conservative approach has be- - ised to determine "upe limit" values for potential adverse

effects resulting from the nuclear and conventional construction phases of the project. Within the limitations of the study, it has been concluded that there are no technical, safety, or operational factors. which would preclude the successful implementation of this p-oject.
\end{abstract}

\section{Introduction}

This paper summarizes the finding of a preliminary survey by Lawrence Livermore Laboratory (LLL) of the possibility of excavating a portion of Route $5 \mathrm{~A}$ across the Isthmus of Kra with the aid of nuclear explosives. It is based on an earlier sicidy of January 1973 which was updated during March and April 1973. This survey does not claim to be a detailed design, nor, indeed, a feasibility study. Emphasis has been on evaluating those issues which might rule out the possibility of nuclear excavation at this stage, and on providing a basis for comparing the safety, operational, and economic factors of the nuclear option with those of conventional excavation.

Within the limitations of the present study, it is concluded that the nuclear excavation could be successfully accomplished; no technical, safety, or operational issues have been found which would preciude carrying out this project.

\section{Assumptions}

The assumptions used in evaluating this project include:

1) A canal that is wide and deep enough in cross section (i.e., one having a sufficiently large "navigation prism") to accommodate tankers of 500,000 DWT.
Concepts for two cross sections were investigated: one for two-way traffic $1600 \mathrm{ft} \times 110 \mathrm{ft}$; and a second for one-way traffic, $650 \mathrm{ft} \times 110 \mathrm{ft}$. Fi fure 1 shows two such vessels in a two-way nuclear cut. 


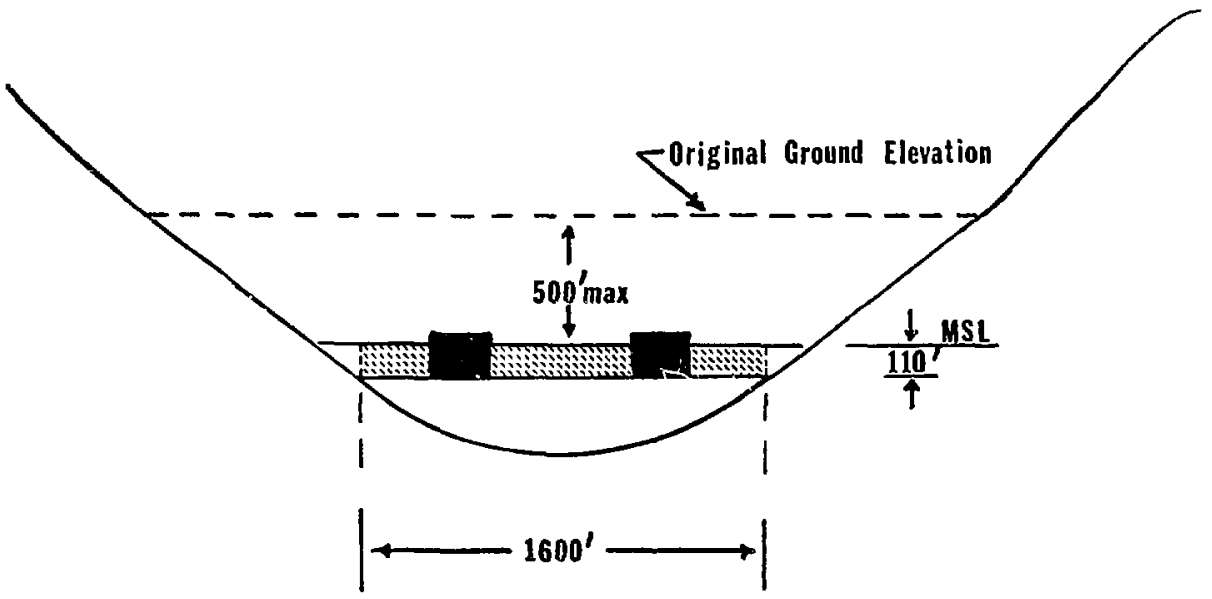

Fig. 1. Cross section of proposed two-way Kra Isthmus canal showing 1600-by-100-ft navigation prism. Black rectangles represent two 500,000-DWT vessels passing in the canal.

2) Crater dimensions based on scaling relations developed from a large number of high-explosive experiments and from the U.S. nuclear excavation experiments. These relations are the same as those used in the 1970 Interoceanic Canal Studies reports.

3) A maximum yield for any individual explosive of $1 \mathrm{Mt}$ (megaton).

4) A maximum salvo yield of about $5 \mathrm{Mt}$.
5) Initial quantities of radionuclides consistent with a modest extrapolation of existing nuclear excavation explosive technology.

6) Quantities of radionuclides injected into the atmosphere consistent with U.S. nuclear cratering experience.

7) Ground motion experience from U.S. detonations applicable to the Isthmus of Kra.

\section{Uncertainties}

We believe a number of areas presently not known or imprecisely known should be enumerated so that the limitations of this survey may be understood. This enumeration will also serve to indicate some of the answers whicit should be obtained during any subsequent feasibility and design studies.
1) The largest U.S. cratering experiment had a yield of $100 \mathrm{kt}$ (kilotons) in alluvium, and the largest U.S. row-charge experiment consisted of five 1-kt explosions. While extrapolating to a 5-Mt salvo is uncertain, there exists no evidence to suppe.t significant departures from known scaling relations. 
2) Details of thi geology, bydrology, and rock properites on Route $5 \mathrm{~A}$ are not known, but would have to be obtained to refine the present detonation plan.

3) No nuclear experiments (cratering or contained) have taken place in limestone, which is apparently the dominant rock of the divide portion of Route $5 \mathrm{~A}$.

4) Detailed ground motion and structural damage predictions must await a more complete study.

5) Times needed to drill the emplacement holes - especially those in material disturbed by previously fired salvos are not known for the rocks of Route $5 A$.

6) The amouni of conventional remedial work in the coninecting areas between the individual salvos is unknown, but it is not expected to exceed a tenth of the nuclearly excavated volume.

7) Details of the pathways by which radioactivity can reach the local population depend on food chains and the retention of activities along such pathways. These have not been studied in detail.

\section{Route Locations and Characteristics}

The location of Route $5 \mathrm{~A}$ in relation to several other routes previously examined is shown in Fig. 2. Route $5 \mathrm{~A}$ was selected because of the relatively low population density of the area that would have to be evacuated, its low average elevation, and other economic considerations. Iis totai length is about $100 \mathrm{~km}$. As can be seen in Fig. 3, a surface profile along the alignment shows a maximum elevation of about $\mathrm{i} 50 \mathrm{~m}$. A similar profile which includes surface geology is shown in Fig. 4. This geology comes from published reports. (A more detailed study from field observations is in Appendix B, Part V, of the TAMS/RRNA report referenced in the $P$ : eface.)

\footnotetext{
*The maximum elevation of the highway along Route $5 \mathrm{~A}$ is $100 \mathrm{~m}$. Because of the $r$ ugged terrain and the width of the canal, a maximum elevation of $150 \mathrm{~m}$ has been used in the present work.
} 


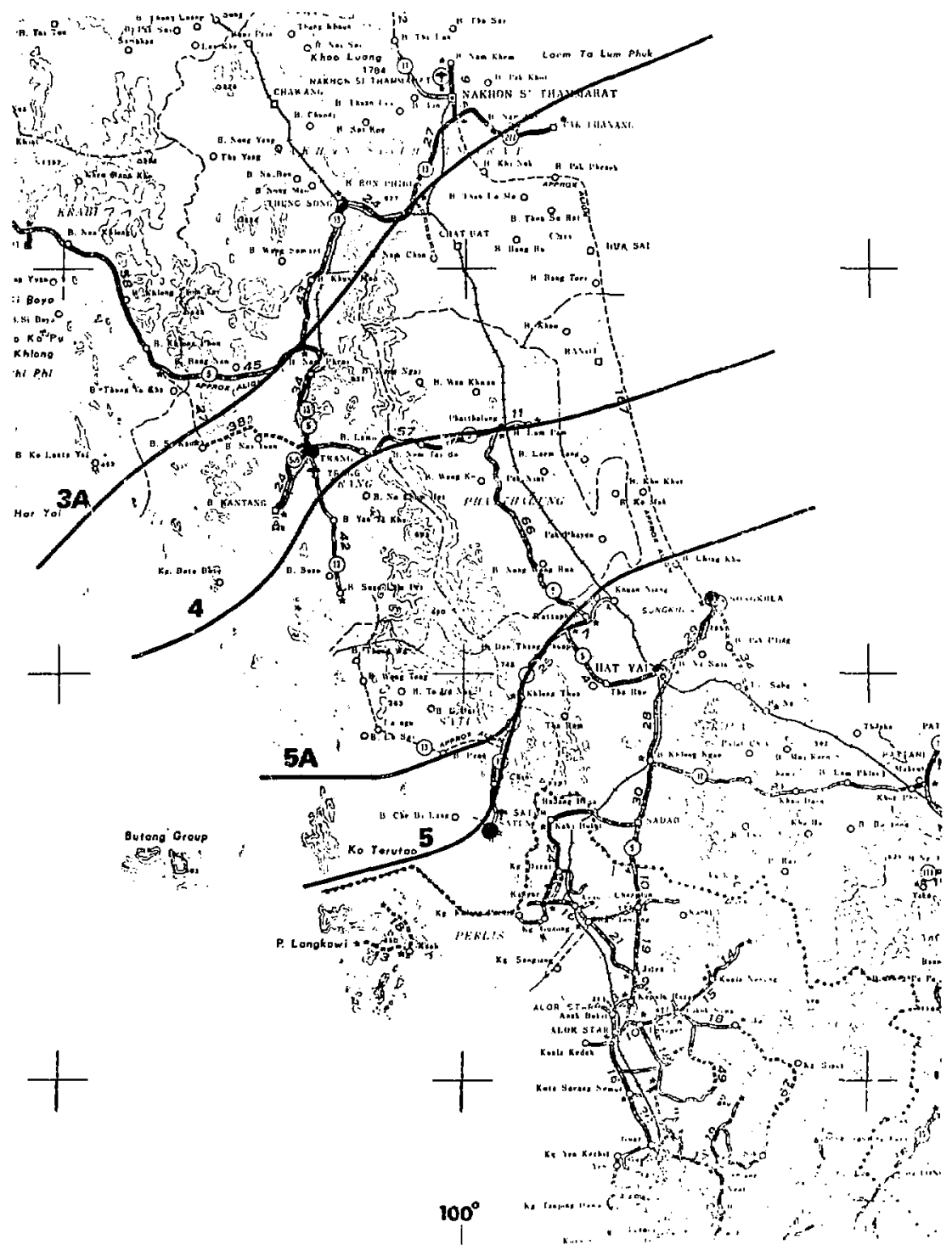

Fig. 2. Possible sea-level caral routes across the Kra Isthmus. 


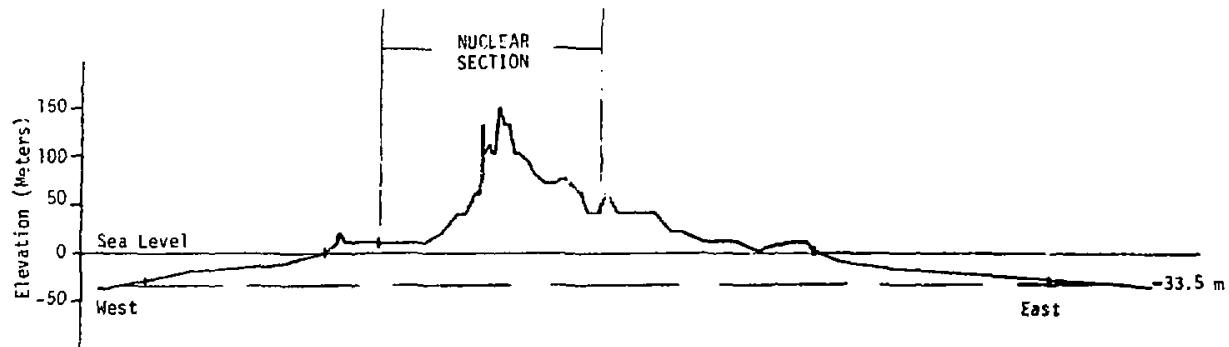

Vertical Exaggeration 200:1

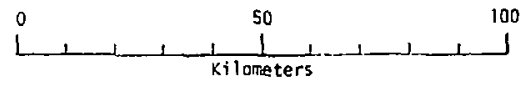

Fig. 3. Surface elevations along Route 5A.

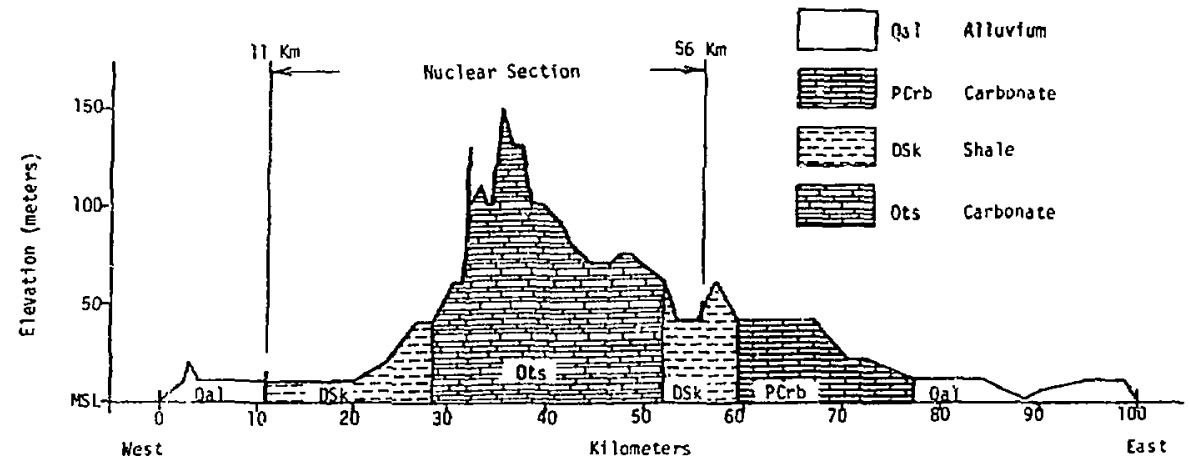

Verticat Exaggeration 200:-

Qa] Alluvium

Quarternary to Recent

PCrb Ratburi Group

Ratburi Fm,

Carboniferous \& Permian

Massive limestone interbedded with

shale, sands tone, mudstone,

conglemerate \& volcanic iff
DSk Tanaosi Group
Kanchanahuri Fim.
Devonian and Stiurian

Shale, sandstorte and sartoy shale of ten metamorphased to phyilite argillite, quartzite and slate. Bedded ilmestone locally present

Ots Thung Song Group Thung Song $\mathrm{Fm}$. Ordovictan

Massive limestone interbedded with calcareous shate and sandy shale.

Fig. 4. Schematic surface geology along Route 5A. 


\section{Nuclear Excavation Plan}

Two detonation plans, corresponding to one-way and two ay navigation prisms for 500,000-ton tankers, have been jeveloped. Table 1 summarizes yields, Galvos, tentative locations, and number of explosives for the two-way 1600-ft $\times 110-f t$ navigation prism, while Table 2 presents the corresponding data for the one-way 650-ft $\times 110-\mathrm{ft}$ prism. As these tables show, the excavation for the large pris"l requires 113 explosives distributed among 21 salvos for a total yield of $105 \mathrm{Mt}$. The small prism requires a larger number of explosives, 139, but

Table 1. Detonation plan for the two-way canal (1600 ft $\times 110 \mathrm{ft}$ ) along Route $5 \mathrm{~A}$. (The first $10.9 \mathrm{~km}$ at the west end of the route and the final $45.6 \mathrm{~km}$ at the east end would be done by conventional excavation, and the $45.1 \mathrm{~km}$ in between would be done by nuclear excavation.)

\begin{tabular}{|c|c|c|c|c|c|c|}
\hline \multirow{2}{*}{$\begin{array}{c}\text { Salvo } \\
\text { number }\end{array}$} & \multicolumn{2}{|c|}{$\begin{array}{c}\text { End point } \\
\text { locations }(\mathrm{km})^{\mathrm{a}}\end{array}$} & \multirow{2}{*}{$\begin{array}{l}\text { Total } \\
\text { yield } \\
\text { (Mt) }\end{array}$} & \multirow{2}{*}{$\begin{array}{l}\text { Total number } \\
\text { of explosives }\end{array}$} & \multicolumn{2}{|c|}{$\begin{array}{c}\text { Number of explnsives } \\
\text { by yield (Mt) }\end{array}$} \\
\hline & West end & East end & & & & \\
\hline- & 0 & 10.9 & - & - & - & - \\
\hline 1 & 11.00 & 13.70 & 4.9 & 7 & 7 & - \\
\hline 2 & 14.15 & 16.85 & 4.9 & 7 & 7 & - \\
\hline 3 & 17.30 & 19.99 & 4.9 & 7 & 7 & - \\
\hline 4 & 20.44 & 23.14 & 5.2 & 7 & 6 & 1 \\
\hline 5 & 23.64 & 25.64 & 5.0 & 5 & - & 5 \\
\hline 6 & 26.14 & 28.15 & 5.0 & 5 & - & 5 \\
\hline 7 & 28.65 & 30.55 & 5.0 & 5 & - & 5 \\
\hline 8 & 30.99 & 32.56 & 5.0 & 5 & - & 5 \\
\hline 9 & 32.88 & 34.11 & 5.0 & 5 & - & 5 \\
\hline 10 & 34.44 & 35.59 & 5.0 & 5 & - & 5 \\
\hline 11 & 35.83 & 36.84 & 5.0 & 5 & - & 5 \\
\hline 12 & 37.11 & 38.19 & 5.0 & 5 & - & 5 \\
\hline 13 & 38.49 & 39.77 & 5.0 & 5 & - & 5 \\
\hline 14 & 40.10 & 41.44 & 5.0 & 5 & - & 5 \\
\hline 15 & 41.78 & 43.23 & 5.0 & 5 & - & 5 \\
\hline 16 & 43.62 & 45.19 & 5.0 & 5 & - & 5 \\
\hline 17 & 45.59 & 47.19 & 5.0 & 5 & - & 5 \\
\hline 18 & 47.58 & 49.13 & 5.0 & 5 & - & 5 \\
\hline 19 & 49.52 & 51.21 & 5.0 & 5 & - & 5 \\
\hline 20 & 51.64 & 53.43 & 5.0 & 5 & - & 5 \\
\hline 21 & 53.93 & 55.93 & 5.0 & 5 & - & 5 \\
\hline- & 56.0 & 101.6 & - & - & - & - \\
\hline 21 & - Tot & - & 104.9 & 113 & 27 & 86 \\
\hline
\end{tabular}

${ }^{\text {a }}$ Locations with respect to the kilometer scale shown in Figs. 3 and 4. 
Table 2. Detonation plan for the one-way canal $(650 \mathrm{ft} \times 110 \mathrm{ft}$ ) along Route $5 \mathrm{~A}$. (The first $10.9 \mathrm{~km}$ at the west end of the route and the final $45.6 \mathrm{~km}$ at the east end would ba done by conventional excavation, and the $45.1 \mathrm{~km}$ in between would be done by nuclear excavation.)

\begin{tabular}{|c|c|c|c|c|c|c|c|c|c|c|c|}
\hline \multirow{2}{*}{$\begin{array}{c}\text { Salun } \\
\text { number }\end{array}$} & \multicolumn{2}{|c|}{$\begin{array}{c}\text { End point } \\
\text { locations }(\mathrm{km} \text { )a }\end{array}$} & \multirow{2}{*}{$\begin{array}{l}\text { Total } \\
\text { y!eld } \\
\text { (Mt) }\end{array}$} & \multirow{2}{*}{$\begin{array}{c}\text { Total } \\
\text { number of } \\
\text { explosives }\end{array}$} & \multicolumn{7}{|c|}{ Number of caplosives by yieid (Niv) } \\
\hline & & Enst end & & & & 0.15 & 0.2 & 0.3 & 0.5 & 0.7 & 1.0 \\
\hline- & 0 & 10.9 & - & - & - & - & - & - & - & - & - \\
\hline 1 & 11.0 & 24.04 & 5.30 & 53 & 53 & - & - & - & - & - & - \\
\hline 2 & 24.29 & 31.37 & 4.95 & 24 & - & 9 & $\mathfrak{9}$ & 6 & - & - & - \\
\hline 3 & 31.71 & 34.72 & 5.0 & 8 & - & - & - & 1 & 1 & 6 & - \\
\hline 4 & 35.17 & 37.11 & 5.0 & 5 & - & - & - & - & - & - & 5 \\
\hline 5 & 37.61 & 40.36 & 5.2 & 7 & - & - & - & - & 6 & - & 1 \\
\hline 6 & 40.81 & 44.87 & 5.5 & 11 & - & - & - & - & 11 & - & - \\
\hline 7 & 45.28 & 48.94 & 5.0 & 10 & - & - & - & - & 10 & - & - \\
\hline 8 & 49.35 & 55.98 & 5.4 & 21 & - & - & 11 & $\mathrm{G}$ & 1 & - & - \\
\hline - & 56.0 & 101.6 & - & - & - & - & - & - & - & - & - \\
\hline 8 & - Tota & $s-$ & 41.35 & 139 & 53 & 9 & 20 & 16 & 29 & 6 & 6 \\
\hline
\end{tabular}

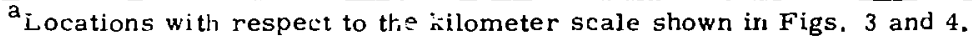

only 8 salvos and a total yield of about $41 \mathrm{Mt}$. Moreover, 98 of these 139 explosives have an individual yield of about $300 \mathrm{kt}$ or less, and thus represent a smaller extrapolation from present experience than the $1-\mathrm{Mt}$ craters. As will be seen later, the relatively small number of salvos for the small prism permits a considerably more rapid operation than that needed for the large prism, which may offset the cost inherent in the small prist's larger number of explosives.

\section{Predicted Effects of the Nuclear Detonations}

\section{LOCAL FALLOUT AND ASSOCIATED RADIOACT YITY}

The $r$ fuired direction for the deposition of fallout was chosen to be to the west, in the sector between 255 and $285^{\circ}$. Assuming that the main cloud from each salvo would rise to a beigrt of $55,000 \mathrm{ft}$, 26 days with favorable winds occurred during the period 15\$6-1972, for an average of about four days per year (see Table 3). If experience shows that such a cloud height is not reached, the number of acceptable days would be larger than those shown in Table 3 . Consideration was given to depositing fallout to the east with summer monsoon winds. However, such winds extend to an altitude of only 30,000 ft. Above that altitude, the winds almost always blow to the west. Consequently, fallout would extend in both directions. In addition, the stronger wind speeds associated with the monsoon winds would carry higher levels of radioactivity to greater distances. It is 
Table 3. Acceptable detonation days for 55,000 - ft cloud height. (Data based on the period 1866-1972 when there were 26 days on which wind conditions were such that a nuclear detonation of the size proposed here, assuming a 55,600-ft-high cloud, would have been acceptable. This table shows the monthly distribution of acceptable days during the period.)

\begin{tabular}{lc}
\hline Month & $\begin{array}{c}\text { Number of } \\
\text { acceptable days }\end{array}$ \\
\hline January & 2 \\
February & 2 \\
March & 3 \\
April & 3 \\
May & 1 \\
June & 1 \\
july & 0 \\
August & 0 \\
September & 0 \\
October & 5 \\
November & 4 \\
December & 5 \\
\hline
\end{tabular}

likely that fallout deposited on Cambodia and South Vietnam would result in greater exposures than those calculated for the Nicobar Islands and Indonesia with winds to the west for the Route $5 \mathrm{~A}$ example. The integrated fallout pattrisn for all Route SA salvos has been calculated to define the downwind exclusion area. An expostire of $0.30 \mathrm{R}$ would be one of the controlling elements of the exclusion zone boundary if the nuclear excavations are carried out in two separate calendar years. Figure 5 shors the $0.17-\mathrm{R}$ lifetime dose contours, resulting from three sal ros in the center of the alignment, for people reentering the area at various times after the detonation. This provides a guide to the time required until evacualed areas can be resuttled by the general population.

\section{I.ONG-RANGT RTUU TRAIECTOR!ES}

Figure o shows a typical debris cloud trajectory for either the base surge or the: main eloud. The possible reversal of the cloud over Sumatra is wel established in the climatological wind studies publisined for the Indian Ocean and Southeast Asia. Because of weather data uncertainty. the possibility that a few clouds may turn northward to the Bay of Bengal cannot at this time be ruled out. Other clouds may travel further west before reversing. Large cloud diffusion calculations were made for the six acceptable detonation days in 1970 and were summed for all salvos. Those nuclides which gave the largest doses were identified and are tabulated in Table 4 for the Nicobar sslands and Surratra. Estimates for both prism sizes are shown. The values given are significantly lower than those in a similar table in previous studies for two reasons: In the case of the Nicobar Islands, it has been more realistically assumed that the clouds from only some of the salvos will pass over the islands; for Sumatra, a more thorough assessment of the major food pathways has eliminated the pasture-meat pathway as a significant factor.

Rainout is unlikely in Thatland or the Nicobar Islands since detonations are planned to occur during the dry season. Sumatra has its heaviest rains in the winter and early spring, but rainclouds seldom exceed $25,000 \mathrm{ft}$. This would rain out most of the base surge, but less than 


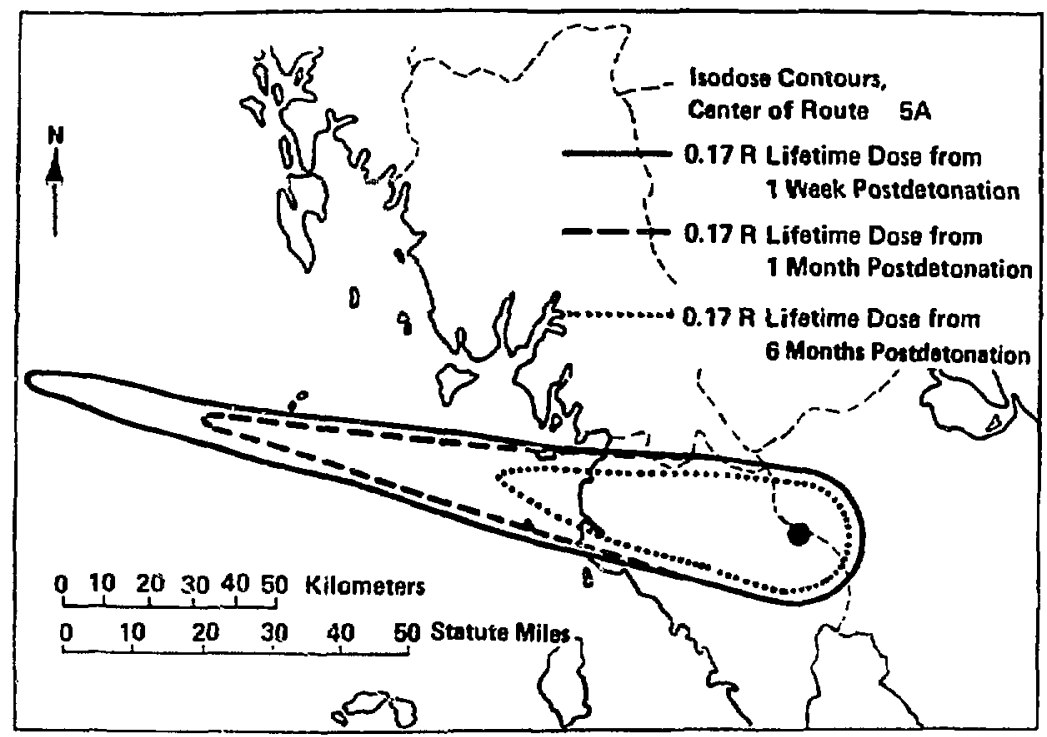

Fig. 5. Calculated fallout pattern from three 5-Mt slavos in the center of the nuclear alignment.

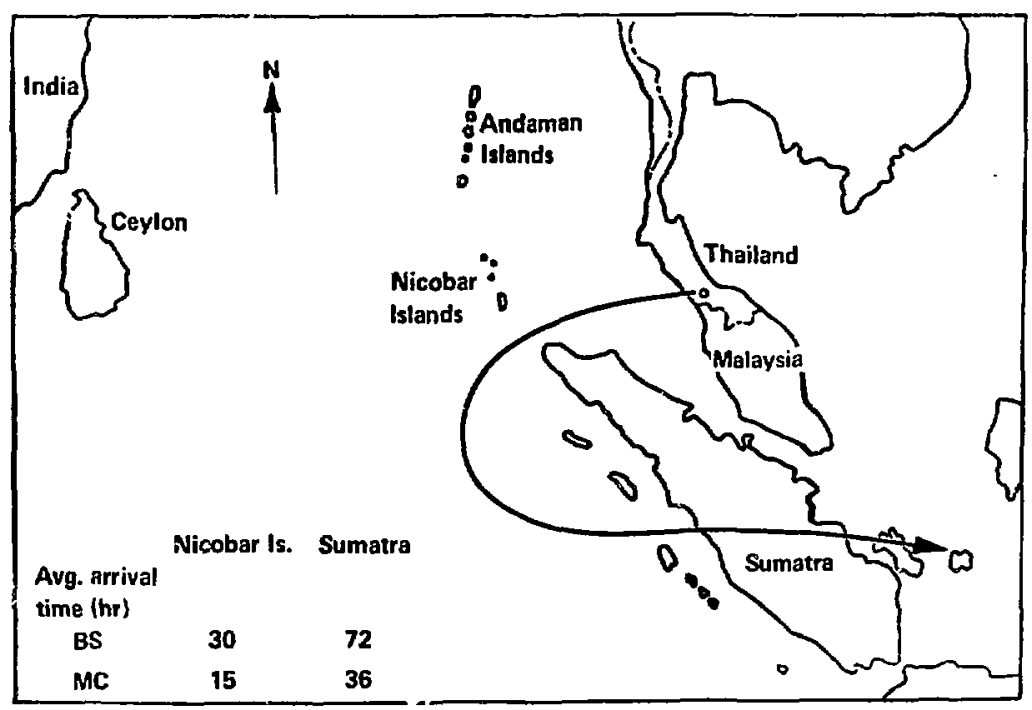

Fig. 6. Typical trajectory for both the base surge cloud (BS) and the main cloud (MC). 
half of the main cloud. Local "hot spots" may develop but they would not be in the same place for each salvo. For such very limited areas, dose enhancement might amount to a factor of 10 to 100 for a single detonation, but the total dose from the entire project would increase only by a factor of 3 .

\section{BIO-ENVIRONMENTAL CONSIDERATIONS}

Internal radiation doses will occur via the inhalation and food-chain pathways. The primary sources of ingested radionuclides via the food chains are fish and rice, the two major components of the Southeast Asian diet. As shown in Table 4, the total exposure from inhalation and food pathways for the Nicobar Islands is upproximaleiy 5 mrem for the one-vay canal. An additional 10 mrern would result from direct fallout. Exposures from external gamma irradiation, inhalation, and food pathways for Sumatra for clouds following trajectories similar to that shown in Fig. 6 is less than 1 mrem.

In this region of the world, aquatic biota contribute the major portion of protein to the diet. Included are iresh-water species, which are raised and harvested in the rice

Table 4. Potential exposures at Nico'sar Islands $(650 \mathrm{~km})$ and Sumatra $(2000 \mathrm{~km}) \mathrm{cal}$ culated for two-way and one-way canal concepts, assuming dry deposition (no rainout). (Based on lone-range cloud trajectories from the six acceptable detonation days in 1970, with contributions from all salvos summed.)

\begin{tabular}{|c|c|c|c|c|c|}
\hline \multirow{3}{*}{$\begin{array}{l}\text { Exposure } \\
\text { pathway }\end{array}$} & \multirow{3}{*}{$\begin{array}{l}\text { Contriouting } \\
\text { radionuclides }\end{array}$} & \multicolumn{4}{|c|}{ 30-yr integral dose (mrem) } \\
\hline & & \multicolumn{2}{|c|}{ Nicobar Islands } & \multicolumn{2}{|c|}{ Sumatra } \\
\hline & & Two-way & One-way & Two-way & One-way \\
\hline External gamma & $\begin{array}{l}\text { Fission products, } \\
{ }^{181} \mathrm{~W},{ }^{187} \mathrm{~W},{ }^{203} \mathrm{~Pb}\end{array}$ & 10 & 10 & 0.05 & 0.05 \\
\hline Inhalation $^{c}$ & ${ }^{3} \mathrm{H}, 131_{\mathrm{I}},{ }^{133_{\mathrm{I}}}$ & 0.2 & 0.08 & 0.2 & 0.07 \\
\hline Pasture-meat $^{\mathrm{d}}$ & ${ }^{3} \mathrm{H},{ }^{203} \mathrm{Hg},{ }^{181} \mathrm{~W}$ & $-e$ & $-e$ & 0.0007 & 0.0003 \\
\hline Rice $^{f}$ & ${ }^{137} \mathrm{Cs},{ }^{90} \mathrm{Sr},{ }^{3} \mathrm{H}$ & 4 & 4 & 0.3 & 0.3 \\
\hline Seafood ${ }^{f, g}$ & ${ }^{32}{ }_{P}$ & 2 & 0.6 & 0.2 & 0.08 \\
\hline
\end{tabular}

${ }^{2}$ Underlined nuclides are the more significant ones for the given pathway.

${ }^{b}$ For other areas of Indonesia and Malaysia, the individual doses are lower than those for Sumatra.

$c_{\text {The }}{ }^{131_{I}}$ and ${ }^{133}$ I dose is to the thyroid; the ${ }^{3} \mathrm{H}$ dose is to the whole body.

$\mathrm{d}$ In the model for the meat pathway, it is assumed that consumption begins several weeks after cloud passage Hence, potential contributions from relatively short-lived nuclides such as $131 \mathrm{I}$ and $32 \mathrm{P}$ have not been included in this pathway.

Pasture-meat pathway is apparently nonexistent in the Nicobar Islands.

${ }^{\mathrm{f}}$ Dose from ${ }^{90} \mathrm{Sr}$ and ${ }^{32} \mathrm{P}$ is to bone; ${ }^{137} \mathrm{Cs}$ dose is to whole body.

$g_{I n}$ the models for the rice and seafood pathways, it is assumed that conf:mption begins immediately after riloud passage. In the seafood pathway, as an example, there would be a lag time between cloud passage, catch, and consumption. Therefore, the actual dose from the short-lived ${ }^{32} \mathrm{P}$ via the seafood pathway would be much less than in this table. 
paddies, as well as seafood. The drse models used m the Kra calculations are based "por ibserved coricentration factors in marine and freshwater species ${ }^{1}$ and the predicted radionuclide depositions. The dose model for the rice pathway for nuclides other than tritium is based upon observed concentration factors in rice and hulled grain. A special model has been developed to assess the transfer of $3_{1}$ through the large volumes of water involved during the production cycle of rice.

The meat pathway is one for which considerable data is available for determining the transfer of radionuclides to risan and for determining the subseguent dose commitment. However, this pathway is essentially nonexistent in the Nicobar Islands and is of minor importance in Sumatra

All the above pathways have been evaluated using the latest dietary information concerning the average daily consumption of these foods in the Thailand, Malaysia/lndonesia area. As shown in Table 4, the extarnal gamma exposure potentially contributes the greatest dose in the Nicobar Islands. The rice pathway is second in order of importance. For Sumatra, the rice pathway is potentially the primary contributor to the dose, with both the inhalation and seafood pathways being roughly equivalent but lesser in magnitude than the rice pathway. The total doses from

\footnotetext{
${ }^{1}$ S. E. Thompson, C. A. Burton, D. J. Quinn, and Y. Ng, Concentration Factors of Chemical Elements ín Edible Aquatic Organisms, Lawrence Livermore l.aboratory Rept. UCRL-50564 Rev. 1 (1972).
}

all pathways for the Nicobar Islands and Sumatra are about $15 \mathrm{mrem}$ and $1 \mathrm{mrem}$, respectively. For comparison, the average sea-level natural background radiation dose in this area is approximatcly 100 mrem per year.

\section{GROUND MOTION PREDICTIONS}

Predictions of ground motion have been made to aid in establishing the exclusion zone. The acceleration contours for Route 5A are plotted in Fig. 7 . Evacuation of nonproject personnel is probably required within the area bounded by the $0.3-\mathrm{g}$ contour. We note that the $0.3-g$ contour is a controlling element only on the southeastern side of the route alignment.

The extent of minor architectural damage can be estimated by surveying scructures and their foundation materiais: out to about the $0.01 \mathrm{~g}$ contour. For Route $5 \mathrm{~A}$ this contour extends from the southern end of Burma to the middle of West Malaysia, as shown in Fig. 8. The cietail to which such a structure survey would need to be made has not been investigated.

\section{AIRBLAST CONSIDERATIONS}

Direct or close-in airblast is not a controlling factor in establishing the exclusion area and therefore is not a major consideration in nuclear operations. Long-range airblast effects, consisting of the reflection of acoustic energy back to the ground surface at distances of 200 to $300 \mathrm{~km}$, are governed by wind speeds and directions; they can therefore be controlled by constraints on the acceptable 


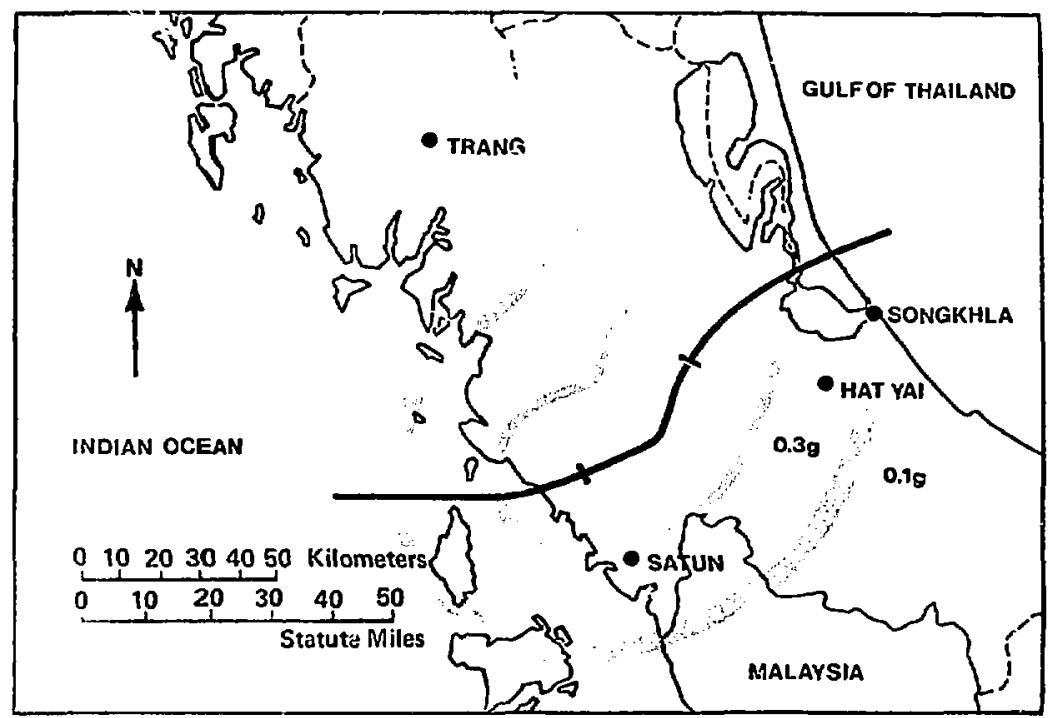

Fig. 7. Ground acceleration contours for Route 5A. (Evacuation of nonproject personnel would probably be required within the $0.3-g$ contour.)

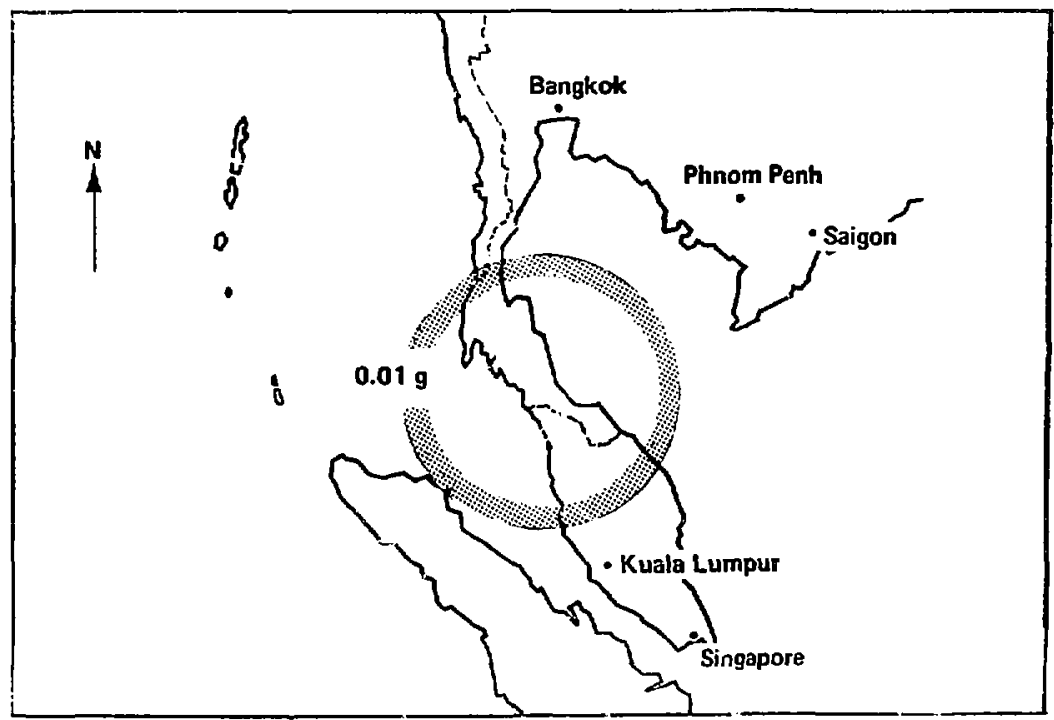

Fig. 8. Long-range ground accelerations. (Minor architectural damage rn ght be expected at points witi:in the $0.01-g$ contour.) 
weather conditions. About $75 \%$ of the days shown in Table 3 to be acceptable from a radioactivity standpoint should also be acceptable from an airblast standpoint.
Detailed upper-air observations on the Isthmus followed by calculations are needed to refine these estimates and to make specific predictions.

\section{Nuclear Operations}

\section{OPERATION CONCEPTS AND SCHEDULES}

For either the one-way or the two-way option, completing the excavation in two passes should utilize manpower and material resources most efficiently. We have assumed employing a total of eight drill rigs for emplacement hole construction. By employing more rigs, the total time could be shortened; the economic tradeoffs have not been studied. This plan envisions that most of the holes would be drilled before any detonation takes place, with only those holes which might be damaged by the first pass being dril'ed between the first and the second prsses. Tables 5 and 6 summarize the construction details for the one-way and two-way options.

Figures 9 and 10 show conceptual schedules for these two options. in both cases, salvo $l$ is at the western limit of the nuclear excavation. As mentioned earlier, the one-way option includes many low-yield explosives; therefore, each salvo contains a relatively large number of explosives, totaling about 5 Mit. The eight salvos can be executed in four detonation days; including four months for contingencies, the nuclear phase for the one-way option could be corcluded in 16 months.

Because each of the craters for the larger navigation prism option is bigger,

Table 5. Emplacement-hole drilling plan for the one-way canal. (On the first drilling pass, all the holes for the first detonation pass are drilled a well as many of those for the second detonation pass. The secund drilling pass is made after the first detonation pass, to drill the remaining holes for the second detonation pass.)

\section{First drilling pass}

Number of holes for first detonation pass

Number of holes for second detonation pass

Total number of holes

123

Total drilling time

18.5 months

(based on 8 drill rigs at $1.2 \mathrm{mo} / \mathrm{hole}=18.5 \mathrm{mo}=1.54 \mathrm{yr}$ )

Second drilling pass

Number of holes (for second detonation pass)

16

Total drilling time

6 months

(based on 8 drill rigs at $3.0 \mathrm{mo} / \mathrm{hole}=6 \mathrm{mo}=0.5 \mathrm{yr}$ ) 
Table 6. Emplacement-hole drilling plan for the two-way canal, (On the first driiling pass, all the holes for the first detonation pass are drilled as well as some of those for the second detonation pass. The second drilling pass is made after the first detonation pass, to drill the remaining holes for the second detonation pass.)

Eirst drilling pass

Nurnber of holes for first detonation pass

Number of holes for second detonation pass

Total number of holes

Total drilling time

11 months

(based on $\theta$ drill rigs at $1.2 \mathrm{mo} / \mathrm{hole}=11 \mathrm{mo}=0.92 \mathrm{yr}$ )

Second drilling pass

Number of holes (for second detonation pass)

Total drilling time

15 montus

(based on $8 \mathrm{drill}$ rigs at $3.0 \mathrm{mo} / \mathrm{hole}=15 \mathrm{mo}=1.25 \mathrm{yr}$ )

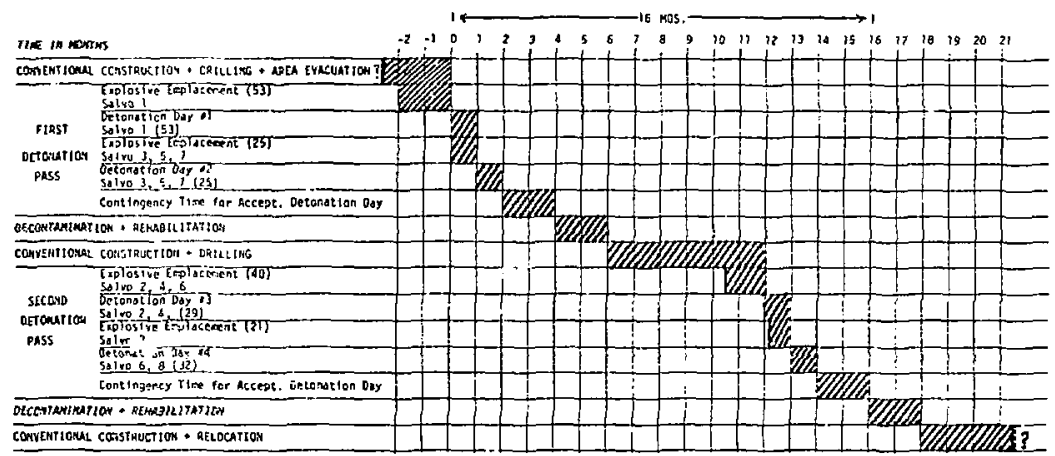

Fig. 9. Schedule of nuclear operatione for the one-way canal.

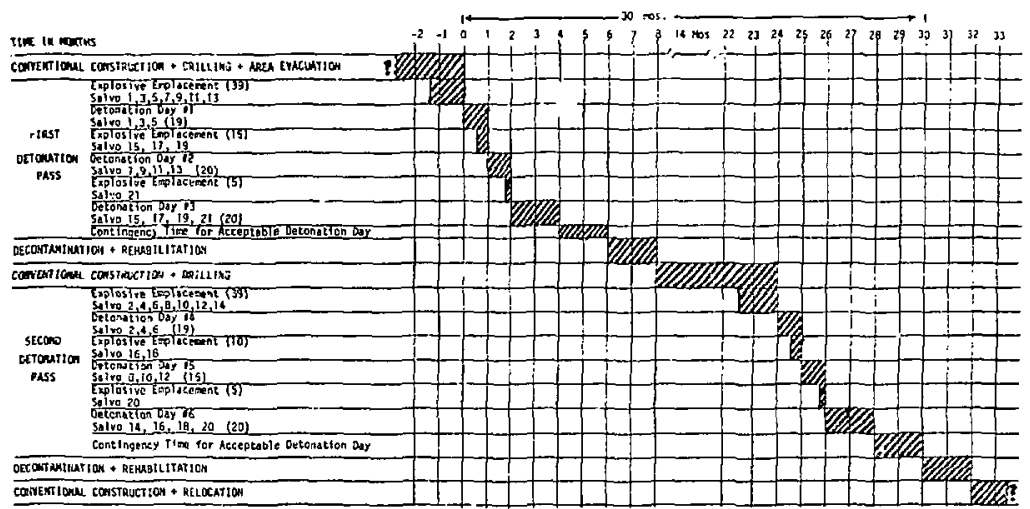

Fig. 10. Schedule of nucleer operations for the two-way canal. 
fewer explosives are needed to cover the same length of excavation. Because of the large individual yields, however, many more salvos and two more detonation days than for the one-way option are required. Again, allowing four months for contingency time, 30 months might be required for the nuclear phase of the two-way option.

\section{EVACUATION AREA}

A factor in considering any nuclear excavation option will be the number of people who have to be evacuated during and following the period of the nuclear detonations. Figure 11 is a map showing the evacuation area for Route $5 \mathrm{~A}$.

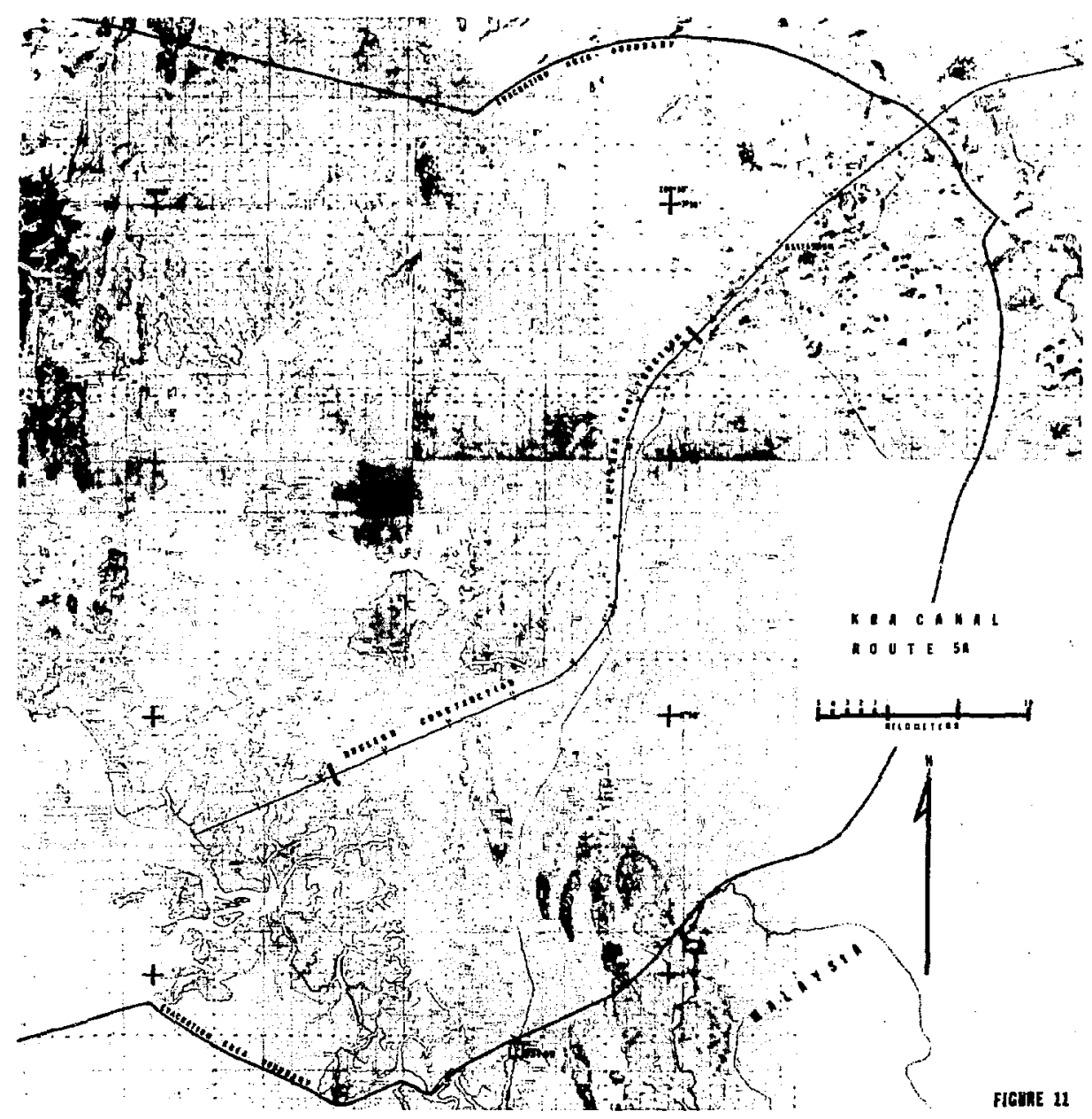

Fig. 11. Evacuation area for Route 5A. 
Evacuation limits to the north, south, and east are roughly determined by the $0.3-\mathrm{g}$ seismic acceleration limit; to the west, boundaries reflect the $255-285^{\circ}$ fallout sector chosen. Natural terrain features have been used to define the exclusion area as much as possible.

It should be noted that none of the population of Malaysia, India, or Indonesia would need to be evacuated.

\section{Summary and Conclusions}

This preliminary assessment of the practicality of constructing, by means of nuclear excavation techniques, a portion of a sea-level canal following Route $5 \mathrm{~A}$ across the Isthmus of Kra has not turned up any factors which would preclude building such a canal. We believe the uclear explosions could be carried out in complete safety without danger to ei her project personnel or the general pof lation. By excluding nonproject personnel from within the $0.3-\mathrm{g}$ acceleration contour and exercising selective control outside this region, the possibility of personal injury from ground motion will be eliminated.

Exclusion will also be necessary to prevent any exposure of people to radioactivity above safe levels. stsch as those recommended by the International Commission on Radiological Protection. Within the national boundaries of Thailand, this requirement can be met by establishing an exclusion area from which the local residents will be evacuated during the detonation phases and for some time afterward. Based on preliminary estimates, fewer than 200,000 people shoulo be affected. No evacuation will be necessary outside the borders of Thailand.

A number of uncertainties remain to be determined during later study and design phases, many dealing with the specifics of the route topography and geology. In addition, a more precise estimate of the nuclear excavation costs needs to be developed. Based on studies which ware done for the Interoceanic

Table 7. Comparative statistics for two-way and one-way canal concepts.

\begin{tabular}{lll}
\hline & Two-way & One-way \\
\hline Navigation prism width and depth (ft) & $1600 \times 110$ & $650 \times 110$ \\
Length of nuclear excavation $(\mathrm{km})$ & 45 & 45 \\
Equivalent conventional volume $\left(\mathrm{m}^{3}\right)$ & $2.4 \times 10^{9}$ & $1.2 \times 10^{9}$ \\
Number of explosives & 113 & 139 \\
Number of salvos & 21 & 8 \\
Total nuclear yield (Mt) & 105 & 41 \\
Number of detonation days & 6 & 4 \\
Time (months) from first detonation to last, & 30 & 16 \\
\hline including contingency time (months) & & \\
\hline
\end{tabular}


Canal, a cost of $\$ 2$ million per detona tion appears at this time to be a reasonable estimate useful for planning purposes. This amount should cover tine nuclear explosive, the emplacement hole, safety studies, and all work related to the detonation. Not included are the costs for relocating local residents and any remedial excavation which might be necessary following the detonation phase.

Table 7 summarizes some of the relevant quantities for the wide and narrow canal options and permits some comparisons to be made. Costs might be about comparable, so the cost per unit volume excavated for the two-way canal is about one-half of that for the one-way canal. Their relative utility depends on ship size and traffic projections, but should be in favor of the two-way canal. These advantages for the two-way canal are gained at a price - larger total yield (but fewer explosives), more salvos (hence, more potentially troublesome connections), more detonation days, a longer operational period, and larger collateral effects such as radiation dones. If tise Kra project if pursued beyond the present survey, all these factors must be consider $d$ in arriving at the best overall design. 